\title{
Effect of milk protein intake and casein-to-whey ratio in breakfast meals on postprandial glucose, satiety ratings, and subsequent meal intake
}

\author{
B. Kung, ${ }^{*}$ G. H. Anderson,† S. Paré, $\ddagger$ A. J. Tucker,ł S. Vien,† A. J. Wright, $\ddagger$ and H. D. Goff ${ }^{\star 1}$ \\ *Department of Food Science, University of Guelph, Ontario, Canada N1G 2W1 \\ †Department of Nutritional Sciences, Faculty of Medicine, University of Toronto, Ontario, Canada M5S 3E2 \\ łDepartment of Human Health \& Nutritional Sciences, University of Guelph, Ontario, Canada N1G 2W1
}

\begin{abstract}
Whey and casein proteins differentially affect postprandial blood glucose and satiety mechanisms, with relevance for type 2 diabetes and obesity. Therefore, the purpose of this work was to investigate the effect of the casein-to-whey protein ratio and total protein concentration of milks consumed with cereal on postprandial blood glucose, appetite ratings, and subsequent food intake in a randomized, controlled, double-blinded study with healthy young adults $(\mathrm{n}=32,23.4 \pm 3.1$ yr, body mass index $\left.=22.2 \pm 2.5 \mathrm{~kg} / \mathrm{m}^{2}\right)$. Fasted participants consumed milk $(250 \mathrm{~mL})$ with either $80: 20$ or 40:60 (modified) casein-to-whey protein ratios at commercially normal $(3.1 \%$, wt) or high protein $(9.3 \%$, wt) concentration, or control (water with whey permeate), each along with 2 servings of oat-based breakfast cereal. Blood glucose concentrations were determined from finger prick blood samples and appetite was assessed using visual analog scales. Participants consumed a measured ad libitum pizza lunch at $120 \mathrm{~min}$ and blood glucose determination and appetite assessment continued following the lunch meal (140-200 min) to observe the second meal effect. Pre-lunch (0-120 min) incremental area under the curve (iAUC) and mean change from baseline blood glucose were reduced with consumption of all milk treatments relative to control. However, we found no differences between all treatments on pre-lunch appetite change from baseline and total area under the curve (tAUC) or lunch meal food intake. In terms of protein concentration results, high protein $(9.3 \%$, wt) treatments contrasted to normal protein $(3.1 \%$, wt) treatments lowered blood glucose change from baseline and iAUC, and post-lunch appetite change from baseline and tAUC. Protein ratio showed a modest effect in that modified (40:60) protein ratio lowered pre-lunch blood glucose change from baseline but not iAUC, and normal (80:20) protein ratio lowered pre-lunch appetite
\end{abstract}

Received January 9, 2018.

Accepted May 31, 2018.

${ }^{1}$ Corresponding author: dgoff@uoguelph.ca change from baseline but not tAUC. Therefore, highcarbohydrate breakfast meals with increased protein concentration $(9.3 \%, \mathrm{wt})$ could be a dietary strategy for the attenuation of blood glucose and improved satiety ratings after the second meal.

Key words: dairy protein, whey, casein, glycemia, appetite

\section{INTRODUCTION}

Metabolic diseases are on the rise globally, with type 2 diabetes and obesity as leading concerns in human health. Obesity is now recognized as a risk factor for type 2 diabetes and can occur concurrently (Eckel et al., 2005). Thus, there is impetus to develop dietary strategies for the risk reduction and management of obesity and diabetes to empower consumers to improve their personal health. The role of the breakfast meal and composition has received relatively little attention beyond the high glycemic index attributed to many high-carbohydrate foods consumed at breakfast. However, these foods are often consumed with a source of protein, including dairy and eggs, which modify the postprandial glycemic response. Frequent consumption of cow milk and dairy products has been associated with lower risk of obesity and type 2 diabetes (Anderson et al., 2011). Meal studies have specifically shown that milk consumed with a high-glycemic, ready-to-eat breakfast cereal consumed by young adults (Law et al., 2017a) or cheese and yogurt consumed with toast and jam by older adults (Law et al., 2017b) markedly lower postprandial glycemia compared with the carbohydrate alone.

The lower postprandial glycemia occurring when dairy is consumed with carbohydrates may be explained by dairy casein and whey proteins, which are present in an 80:20 ratio and have different AA compositions, physical structures, and physiological properties. Casein is higher in methionine, phenylalanine, proline, and histidine; whey proteins have higher amounts of lysine, threonine, tryptophan, leucine, and isoleucine. Based on the rise of their plasma AA concentrations 
postingestion, whey proteins have been referred to as rapidly digested proteins and found to pass relatively quickly through the stomach. In contrast, caseins are considered to be slowly digested (Dangin et al., 2002; Hall et al., 2003) due to forming cross-linked aggregates that delay gastric emptying (Boirie et al., 1997). Consumption of whey protein increases early feelings of satiety and reduces food intake, whereas the effect of casein occurs later (Anderson et al., 2004). For example, consumption of 45 to $50 \mathrm{~g}$ of whey protein decreased food intake more than casein at a meal interval of 30 to 90 min (Anderson and Moore, 2004), but casein consumption reduced food intake more than whey protein at $180 \mathrm{~min}$ (Anderson et al., 2011). Differences in the digestion kinetics of whey and casein proteins facilitate the stimulation of gastric hormones that delay gastric emptying, thus increasing feelings of fullness and attenuation of food particle breakdown and release in the small intestine. Relative to whey, casein digests and releases AA slowly, leading to a delayed stimulation of gastric hormones (Benelam, 2009).

Although the physiological characteristics of whey and casein are well described, the physiological significance of their ratio and concentration in milk are not. Of note, human milk has a ratio of casein to whey approximating 40:60 and a protein content of 1\% (wt; Fox and McSweeney, 1998). Current infant milk formulas often approximate this ratio (Klein, C., 2002), but are higher in protein (2-2.5\%; Martin et al., 2016). Although not recommended in the first year for infants, both the ratio and protein concentration change to $80: 20$ and $3.1 \%$ (wt), respectively, with the introduction of cow milk.

In addition to the potential for dairy proteins to affect postprandial metabolism, evidence has shown that daily protein intake should be spread equally over 3 main meals, indicating a need to include more protein with the breakfast meal (Mamerow et al., 2014). Therefore, the purpose of our work was to test the effect of novel milk formulations with altered amounts and proportions of whey and casein proteins on postprandial blood glucose (BG), feelings of satiety, and subsequent food intake when consumed with a high-glycemic carbohydrate breakfast cereal in healthy young adults. Milk products containing similar protein content as commercial milk (3.1\%, wt, protein) or increased to 9.3\% (wt), both formulated to contain either a 80:20 or 40:60 casein-to-whey ratio, were consumed with breakfast cereal containing a total of $76.7 \mathrm{~g}$ of available carbohydrates. We hypothesized that the milk products containing modified 40:60 casein-to-whey protein ratios or enhanced protein concentrations or both, when compared with the control and commercial milk $(3.1 \%$, wt, concentration and 80:20 ratio), would be associated with reductions in post-lunch BG, enhanced feelings of satiety, reductions in food intake at a subsequent meal, and reductions in BG following the subsequent meal.

\section{MATERIALS AND METHODS}

\section{Treatment Preparation}

Breakfast drinks (250 mL) based on skim milk (Neilson Dairy-Saputo Dairy Products Canada G.P., St-Laurent, Quebec) or control (water with whey permeate) were formulated and cold-mixed together using whey permeate (DariSweet 200, \#215503), skim milk powder (Low Temp, \#202001), and whey protein concentrate (Prodel 35, \#33703; all from Parmalat Canada, London, ON, Canada) to increase the concentration of commercial milk protein $(3.1 \%$, wt) 3 -fold $(9.3 \%, \mathrm{wt})$ and modify the casein-to-whey protein ratio from (normal) 80:20 to high whey (i.e., 40:60) while holding the lactose $(34.7 \mathrm{~g})$ contents constant (Table 1). Treatments and the water and permeate control were combined with $58 \mathrm{~g}$ of oat-based cereal (Honey Nut Cheerios, General Mills, Mississauga, Canada) to form the breakfast meal, totaling $76.7 \mathrm{~g}$ of available

Table 1. Composition of breakfast drinks served with Cheerios (General Mills, Mississauga, Canada) to participants

\begin{tabular}{lccccc}
\hline Treatment $(250 \mathrm{~mL})$ & $\begin{array}{c}\text { Water } \\
(\mathrm{mL})\end{array}$ & $\begin{array}{c}\text { Skim milk } \\
\text { liquid }(\mathrm{mL})\end{array}$ & $\begin{array}{c}\text { Permeate } \\
\text { powder }(\mathrm{g})\end{array}$ & $\begin{array}{c}\text { Skim milk } \\
\text { powder }(\mathrm{g})\end{array}$ & $\begin{array}{c}\text { Whey protein } \\
\text { concentrate powder }(\mathrm{g})\end{array}$ \\
\hline Control $^{1}$ & 250 & - & 47.3 & - & - \\
$3.1 \%{\text { MKP }(80: 20)^{2}}_{3.1 \% \text { MKP }(40: 60)^{3}}$ & - & 250 & 31.9 & - & - \\
$9.3 \%$ MKP $(80: 20)^{4}$ & -125 & 125 & 31.6 & 46.8 & - \\
$9.3 \%$ MKP $(40: 60)^{5}$ & - & 250 & - & 11.8 & 37.7 \\
\hline
\end{tabular}

${ }^{1}$ Control (water with whey permeate).

${ }^{2}$ Commercial skim milk $3.1 \%$ (wt) milk protein (MKP; 80 casein:20 whey).

${ }^{3}$ Normal 3.1\% (wt) MKP (40 casein:60 whey protein).

${ }^{4}$ High $9.3 \%$ (wt) MKP (80 casein:20 whey protein).

${ }^{5}$ High $9.3 \%$ (wt) MKP (40 casein:60 whey protein). 
carbohydrates from cereal (42 g) and from lactose (34.7 g; Table 2).

\section{Study Design and Protocol}

Healthy young male and female adult participants were recruited from the University of Guelph and surrounding community. Participants met the inclusion criteria of 18 to $30 \mathrm{yr}$ old, healthy, body mass index between 20 and $24.9 \mathrm{~kg} / \mathrm{m}^{2}$, regular milk consumers (>2 servings/week), typical breakfast consumers (before $0900 \mathrm{~h}, 5 \mathrm{~d} /$ week), and fasting $\mathrm{BG}<5.5 \mathrm{mmol} / \mathrm{L}$ (but not $<3.5 \mathrm{mmol} / \mathrm{L}$ ). Exclusion criteria consisted of the presence of any medical condition, including gastrointestinal disorders, regular medication use (excluding hormonal contraceptives), any food allergy or anaphylactic allergy or both, smoking, and recreational drug use. Elite or training athletes were excluded, along with individuals trying to lose weight or whose BW had changed $>5 \mathrm{~kg}$ within the previous 6 mo. Participants were excluded if they scored $>16$ on the cognitive restraint scale on the three-factor eating questionnaire (Stunkard and Messick 1985). Additionally, persons regularly consuming a high number of caffeinated ( $>4$ drinks/day) or alcoholic drinks ( $>14$ drinks/wk), taking protein supplements, or who were pregnant or breastfeeding were excluded. The study was approved by the University of Guelph Human Research Ethics Board (\#14JN004) and was registered with clinicaltrials.gov (NCT02471092) and all participants provided written informed consent.

A double-blinded, controlled, crossover randomized design was used. Healthy men and women (16 males and 16 females) randomly consumed 1 of each of the 5 allocated 3 -digit number coded treatments at study visits separated by 1 wk. On study visit days, participants arrived at the Human Nutraceutical Research Unit at the University of Guelph after a 12-h overnight fast. Water was allowed up to $1 \mathrm{~h}$ before the start of each session. Upon arrival, participants filled out a questionnaire on sleep habits and stress factors. Participants who indicated feelings of illness, atypical sleep, or stress were asked to reschedule. Satiety was measured using a 100-mm visual analog scale self-reported paper questionnaire with hunger, fullness, desire to eat, and prospective food consumption horizontal anchored scales (i.e., not at all hungry versus extremely hungry; Blundell et al., 2010). Baseline finger prick blood samples for glucose concentration were obtained in duplicate and analyzed using a glucose meter (HemoCue Glucose 201+ Analyzer, HemoCue, Angelholm, Sweden). Participants, in isolation, then consumed the treatment or control $(250 \mathrm{~mL})$, served in a large bowl with 2 servings $(58 \mathrm{~g}$ ) of cereal (Honey Nut Cheerios, General Mills) and a glass of $100 \mathrm{~mL}$ of cool water, at a constant pace within $5 \mathrm{~min}$. We added $1.5 \mathrm{~g}$ of crushed acetaminophen (Tylenol, McNeil Consumer Healthcare, Markham, ON, Canada) to each 250-mL serving of breakfast for the purposes of measuring gastric emptying (data not shown). Appetite was assessed before and immediately following breakfast consumption and before finger prick blood samples, and then at 15 - to 30-min intervals thereafter (i.e., 0, 15, 30, 45, $60,90,120,140,155,170,185$, and $200 \mathrm{~min}$ ). A subset of 6 males and 6 females provided blood samples taken by an indwelling venous catheter to allow sufficient blood volume for gastric hormones, acetaminophen, and AA analyses, which will be reported elsewhere. At $120 \mathrm{~min}$, participants, in isolation, were served an ad libitum pizza lunch and instructed to eat until comfortably full. The 4-cheese 13-cm pizzas (McCain Foods, Florenceville, NB, Canada) were prepared by baking in an oven at $425^{\circ} \mathrm{F}$ for $10 \mathrm{~min}$. Pizzas were cut into quarter slices and 4 pizzas were served on individual plates (approximately $81 \mathrm{~g} /$ plate) on each tray and served with a 500-mL glass of cool water. Participants were given 6 to $7 \mathrm{~min}$ with each tray, and up to 3 trays were presented during a maximum total lunch

Table 2. Combined composition of milk treatment $(250 \mathrm{~mL})$ with breakfast cereal $(58 \mathrm{~g})$

\begin{tabular}{|c|c|c|c|c|c|c|}
\hline Treatment (250 mL) & $\begin{array}{l}\text { Calories } \\
\text { (kcal) }\end{array}$ & $\begin{array}{c}\text { Available } \\
\text { carbohydrates (g) }\end{array}$ & $\begin{array}{l}\text { Total } \\
\text { fats }(g)\end{array}$ & $\begin{array}{c}\text { Casein } \\
\text { protein }(\mathrm{g})\end{array}$ & $\begin{array}{l}\text { Whey } \\
\text { protein }(g)\end{array}$ & $\begin{array}{c}\text { Total } \\
\text { protein }(\mathrm{g})\end{array}$ \\
\hline Control $^{1}$ & 403.8 & 76.7 & 2.8 & 0 & 0.3 & 4.6 \\
\hline $3.1 \% \operatorname{MKP}(80: 20)^{2}$ & 433.1 & 76.7 & 3.2 & 6.2 & 1.6 & 12.4 \\
\hline $3.1 \% \operatorname{MKP}(40: 60)^{3}$ & 435.6 & 76.7 & 3.0 & 3.1 & 4.8 & 12.4 \\
\hline $9.3 \% \operatorname{MKP}(80: 20)^{4}$ & 485.6 & 76.7 & 3.4 & 18.6 & 4.7 & 27.9 \\
\hline $9.3 \% \operatorname{MKP}(40: 60)^{5}$ & 499.1 & 76.7 & 4.0 & 9.3 & 14.1 & 27.9 \\
\hline
\end{tabular}

${ }^{1}$ Control (water with whey permeate).

${ }^{2}$ Commercial skim milk 3.1\% (wt) milk protein (MKP; 80 casein:20 whey).

${ }^{3}$ Normal $3.1 \%$ (wt) MKP (40 casein:60 whey protein).

${ }^{4}$ High $9.3 \%$ (wt) MKP (80 casein:20 whey protein).

${ }^{5}$ High $9.3 \%$ (wt) MKP (40 casein:60 whey protein). 
period of $20 \mathrm{~min}$. The pizza and water were weighed before and after serving to determine food and energy intakes, which were calculated based on the product label nutritional information. Blood glucose and satiety measurements continued for $1 \mathrm{~h}$ after the pizza lunch (i.e., at 140, 155, 170, 185, and $200 \mathrm{~min}$ ). Participants were also asked to complete questionnaires related to palatability of the breakfast and lunch meals and gastrointestinal symptoms (abdominal discomfort, bloating, cramping, rumbling, flatulence, bowel movement, bowel consistency, problems with defecation function, bowel movement urgency, and overall gastrointestinal function) during the 24-h period following each study visit using an anchored 100-mm horizontal visual analog line scale (Veenstra et al., 2010).

\section{Data and Statistical Analysis}

The sample size of 32 was determined on the basis of previous studies (Law et al., 2017a), which showed that 26 participants would be required to detect a 150 kcal difference in treatment effects on food intake and a $10 \%$ difference in subjective appetite ratings and ad libitum energy intake and considering a $15 \%$ attrition rate. Appetite score was calculated based on the average of individual scales [i.e., (hunger $+(100-$ fullness $)$ + desire to eat + prospective food consumption)/4]. Pre-lunch changes from baseline were calculated from 0 (immediately before breakfast consumption) to $120 \mathrm{~min}$ and post-lunch changes from 120 (before lunch meal consumption) to $200 \mathrm{~min}$. Postprandial glycemia and appetite scores were also explored based on area under the curve (AUC) results. An AUC over $120 \mathrm{~min}$ is a standard measure for the glycemic index and recommended by Health Canada for postprandial glycemia health claims (Health Canada, 2013). Incremental area under the curve (iAUC) for BG and total area under the curve (tAUC) for appetite were calculated using GraphPad Prism version 5 (GraphPad Software Inc., La Jolla, CA). Last, energy intake was calculated by multiplying the weight of the consumed pizza (grams) by the calories per serving, as provided by the manufacturer.

For the statistical analysis, all milk treatments were first compared with the whey permeate control. Specifically, differences in BG and appetite scores change from baseline (pre- and post-lunch) were investigated using a repeated-measures PROC MIXED 3-way (treatment, time, and sex) ANOVA, followed by Tukey-Kramer testing to compare treatments to the control using SAS version 9.3 (SAS Institutes, Cary, NC). Results were pooled for males and females, unless a significant sex effect or sex and treatment interaction or both were found, in which case a 2-way ANOVA (treatment and time) followed by Tukey's post hoc testing was performed to compare the effect of treatment. When an interaction was found, a 2-way ANOVA (treatment and sex for pooled participants) or a 1-way ANOVA (treatment for males and females) followed by Tukey-Kramer testing was performed to identify the effect of treatment at each time point. Blood glucose iAUC, appetite tAUC, and energy intake were all investigated using a repeated-measures PROC MIXED 2-way (treatment and sex) ANOVA, followed by Tukey-Kramer testing. Area under the curve and energy intake results were pooled for males and females unless a significant sex effect or interaction or both was found, in which case a one-way ANOVA (treatment) followed by Tukey's post hoc testing was used to identify differences between treatments within each sex.

Orthogonal contrast statements were also used to group pairs of treatments (not including the whey permeate control) according to (1) protein concentration [mean of $3.1 \%$, wt $(80: 20)+3.1 \%$, wt (40:60) vs. mean of $9.3 \%$, wt $(80: 20)+9.3 \%$, wt (40:60)] and (2) protein ratio [mean of $3.1 \%$, wt $(80: 20)+9.3 \%$, wt $(80: 20)$ vs. mean of $3.1 \%$, wt $(40: 60)+9.3 \%$, wt $(40: 60)]$, to specifically compare the overall effect of protein concentration and ratio for all endpoints.

Linear regression and Pearson correlation coefficient were used to explore associations between appetite change from baseline $(\mathrm{mm})$ and food intake (kcal), with all 4 treatments and the control, significance set at $P$ $<0.05$. Data are presented as mean \pm standard error of the means.

Gastrointestinal questionnaire results were analyzed with a one-way ANOVA when normally distributed or the Kruskal-Wallis test for nonparametric distribution. When significance was found, all 4 treatments and the control were analyzed by Tukey's post hoc test or the Kruskal-Wallis paired test. Normally distributed data are presented as mean \pm standard error of the means and nonparametric data are presented as median followed by interquartile range ( 25 to $75 \%$ ).

\section{RESULTS}

Participant characteristics at the time of study enrolment are presented in Table 3. In total, 271 participants were phone screened, 97 were invited for an in-person eligibility assessment, and 45 were enrolled in the study (Figure 1). Participants were excluded from the study due to scheduling conflict, fasting glucose $>5.5 \mathrm{mmol} / \mathrm{L}$ on the day of study visit, or reasons unrelated to the study. Data for a total of 32 participants, including 1 male participant who only completed 4 study visits, were analyzed. 


\section{Blood Glucose Change from Baseline and iAUC}

Change from baseline (0 min for pre-lunch and 120 min for post-lunch responses) values are reported in Figure 2. Pre-lunch (0-120 min) mean BG change from baseline concentration showed a significant effect of treatment $(P<0.01)$, time $(P<0.01)$, and treatment $\times$ time $(P<0.01)$ and treatment $\times \operatorname{sex}(P<$ $0.05)$ interactions were observed, but we found no sex effect $(P=0.76$; Table 4$)$. All milk treatments differed relative to the water with whey permeate control $(P<$ 0.01). Pre-lunch BG change from baseline concentration peaked at $30 \mathrm{~min}$ for all treatments. Furthermore, when treatments were contrasted by protein concentration or ratio, high-protein treatments $(9.3 \%$, wt) were associated with greater attenuations of $\mathrm{BG}$ change from baseline by $-1.01 \pm 0.12 \mathrm{mmol} / \mathrm{L}$ compared with the normal protein level $(3.1 \%$, wt $)$ treatments $(P<0.01)$. Likewise, regardless of protein concentration, modified protein ratio (40:60) was associated with greater attenuations of $\mathrm{BG}$ by $-0.26 \pm 0.12 \mathrm{mmol} / \mathrm{L}$ compared with the normal ratio $(80: 20)$ treatments over the 120-min pre-lunch period $(P=0.03)$. At specific time points, according to the contrasts, high $(9.3 \%, \mathrm{wt})$ protein concentration attenuated BG change from baseline from 15 to $90 \min (P<0.01)$, whereas the modified (40:60) ratio attenuated $\mathrm{BG}$ change from baseline at $30(P<$ $0.04)$ and $45 \mathrm{~min}(P=0.01)$ in pooled participants. Differences found in treatment $\times$ sex interactions $(P<$ $0.05)$ may be related to the significant contrast results between modified (40:60) and normal (80:20) protein ratios in male $(P=0.02)$, but not female, participants $(P=0.47)$.

Following the pizza lunch meal, BG change from baseline was not affected by treatment $(P=0.49)$ and we found no significant treatment $\times$ time interaction $(P=$ $0.13)$; however, we noted significant effects of time $(P<$ $0.01)$ and sex $(P<0.01)$ and a treatment $\times$ sex interaction $(P<0.01 ;$ Figure 2$)$. Blood glucose post-lunch change from baseline was not different when contrasted between high and normal protein concentrations $(P=$ $0.10)$ or modified and normal ratio $(P=0.69)$. In male participants, BG post-lunch change from baseline concentration was attenuated by high $(9.3 \%$, wt) compared with low $(3.1 \%$, wt) protein concentrations $(-0.43 \pm$ $0.16 \mathrm{mmol} / \mathrm{L}, P=0.01)$, but we found no difference between modified (40:60) and normal (80:20) protein ratio $(P=0.16)$. However, the BG post-lunch change from baseline contrast trends were reversed in female participants, whereby milk treatments were not different by protein concentrations $(P=0.64)$, but modified (40:60) ratio increased BG compared with the normal $(80: 20)$ ratio by $0.31 \pm 0.14 \mathrm{mmol} / \mathrm{L}(P=0.03$; Table 4).

Pre-lunch BG iAUC showed a significant treatment effect $(P<0.01)$, but we observed neither an effect of sex $(P=0.99)$ nor a treatment $\times$ sex interaction $(P=$ 0.42; Table 5). When comparing among all treatments, milk treatments had lower BG iAUC values relative to the control $(P<0.05)$. Furthermore, when a high protein concentration was contrasted with a low protein concentration, high protein attenuated BG iAUC $(-110.05 \pm 22.43 \mathrm{mmol} / \mathrm{L} \cdot \min , P<0.01)$, mirroring the change from baseline trend; however, we found no difference between modified and normal protein ratio $(P=0.23)$ in pooled participants. Overall, high protein $(9.3 \%, \mathrm{wt})$ consumption consistently resulted in greater suppression of pre-lunch BG. Post-lunch BG iAUC values were not affected by treatment $(P=0.24)$ and we found no treatment $\times$ sex interaction $(P=0.22)$, but we did note a significant effect of sex $(P<0.01)$. The sex effect was likely related to significant treatment effects in male participants, but not in female participants $(P=0.04$ and $P=0.79$, respectively). For male participants, the high protein $(9.3 \%$, wt) modified (40:60) treatment resulted in lower iAUC values $(36.7 \pm 6.5 \mathrm{mmol} / \mathrm{L} \cdot \min )$ compared with control $(72.8$ $\pm 10.7 \mathrm{mmol} / \mathrm{L} \cdot \mathrm{min}$; adjusted Tukey-Kramer, $P=$ $0.03)$, but we observed no effect of treatment when high $(9.3 \%, \mathrm{wt})$ protein was contrasted with low $(3.1 \%, \mathrm{wt})$ protein concentrations $(P=0.06)$ or between modified (40:60) and normal (80:20) ratio $(P=0.45$; Table 5$)$. We found no treatment effect in post-lunch BG iAUC in female participants $(P=0.79)$.

Table 3. Baseline characteristics for participants collected during in-person screening

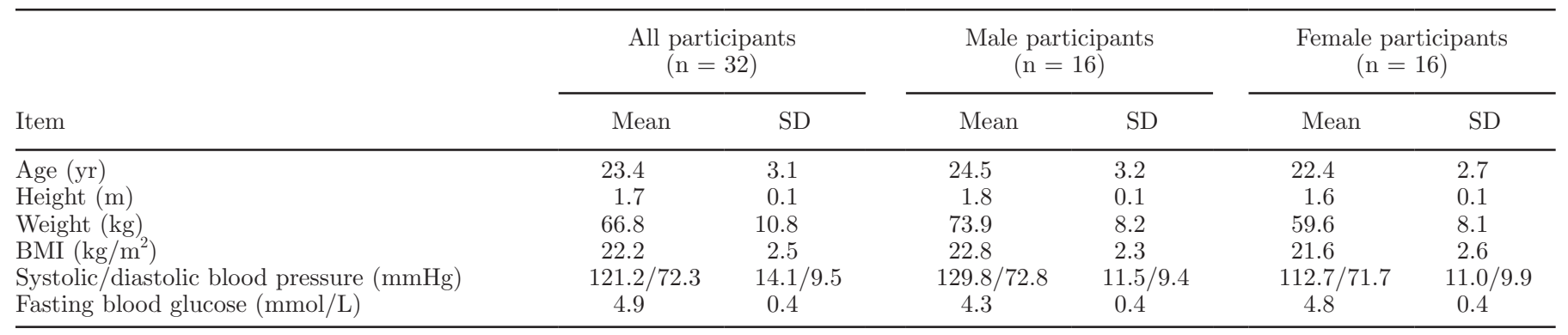


Phone and email screening Assessed for eligibility $(\mathrm{n}=271)$

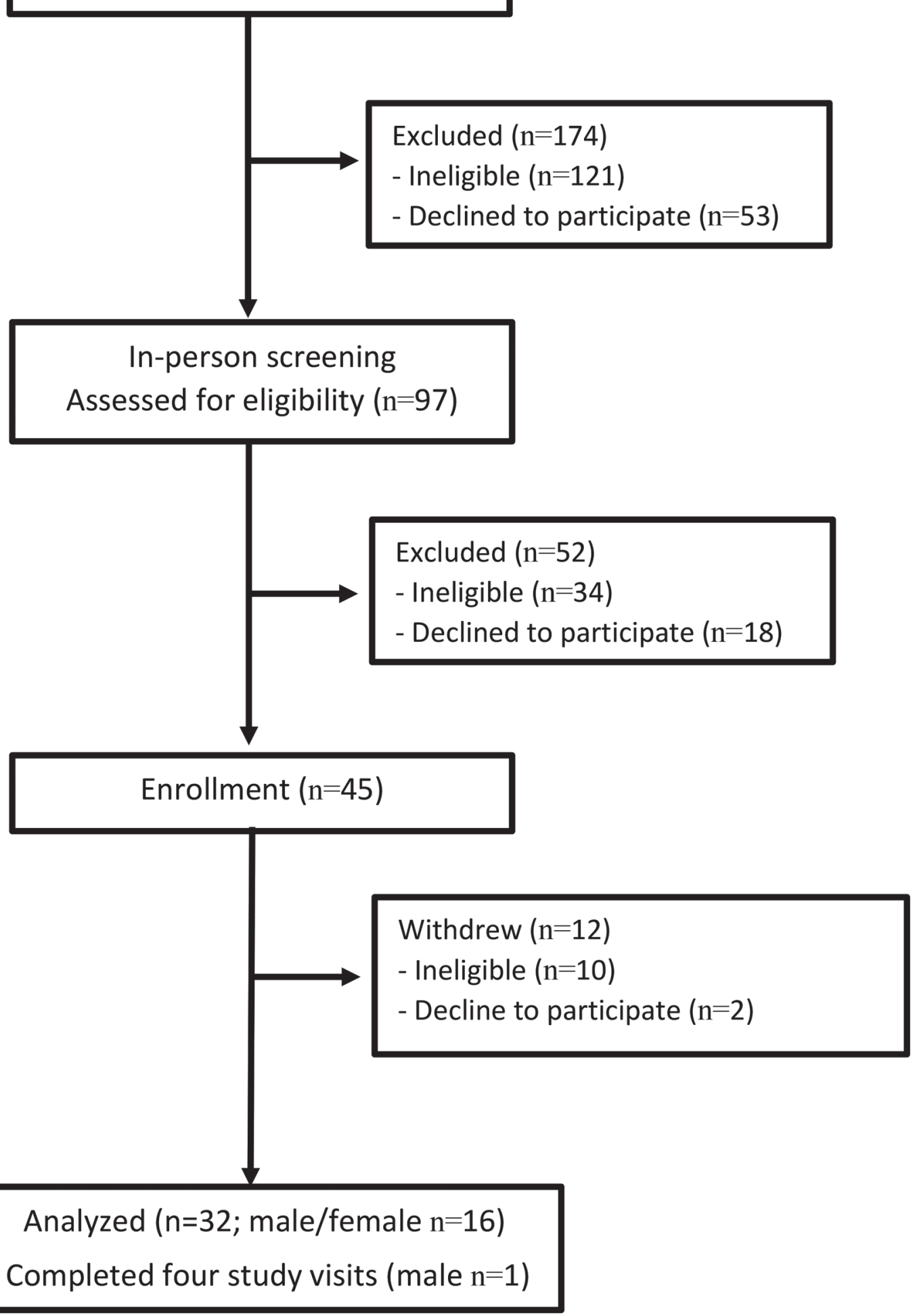

Figure 1. Consolidated standards of reporting trials (CONSORT) flow diagram. 

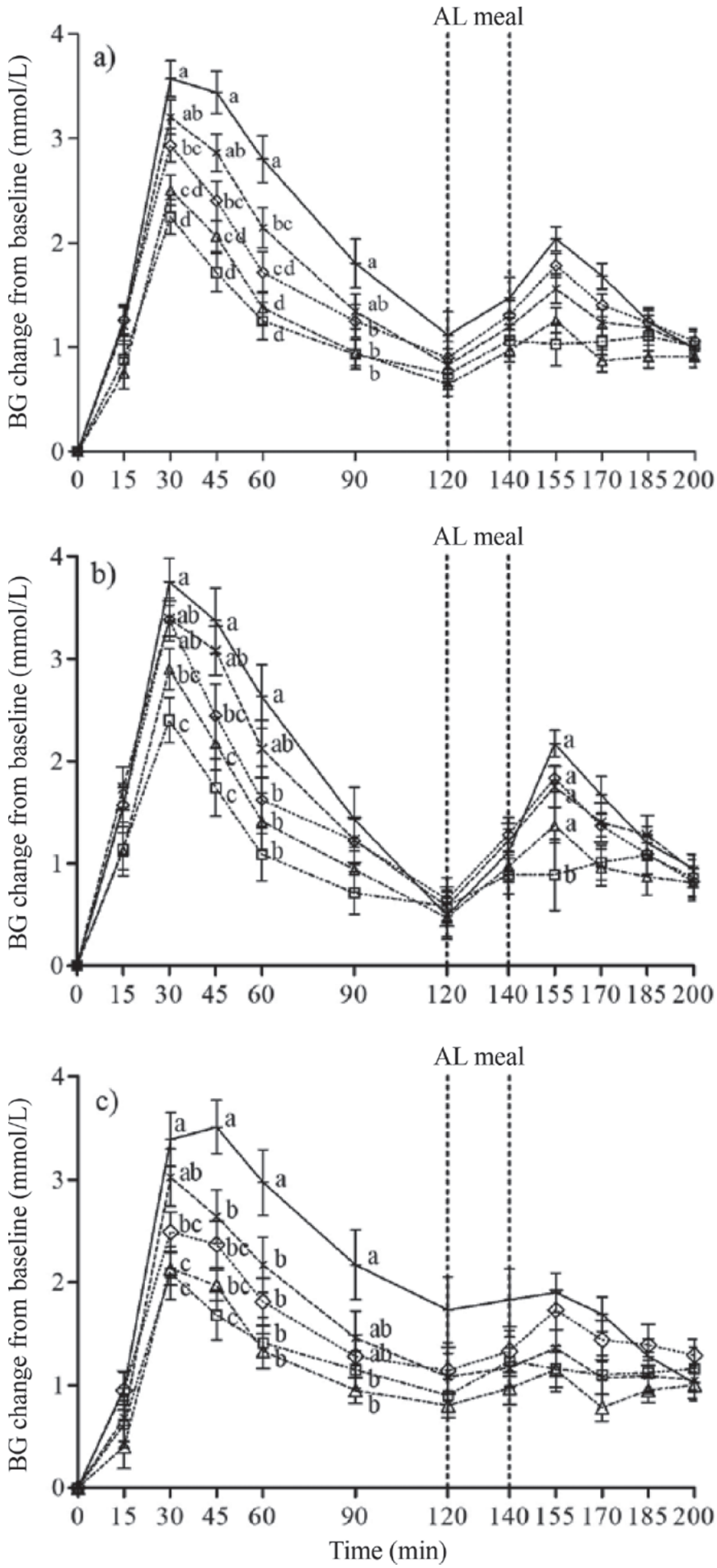

Figure 2. Mean $( \pm$ SEM) blood glucose $(B G)$ change from baseline for (a) all participants $(\mathrm{n}=32)$, (b) male participants $(\mathrm{n}=16)$, and (c) female participants $(\mathrm{n}=16)$ from 0 to 120 min after the consumption of breakfast, followed by a pizza lunch (120-200 $\mathrm{min}$ ) for control $(+), 3.1 \%$ milk protein $(\mathrm{MKP} ; 80$ casein:20 whey protein; $\times), 3.1 \%$ MKP (40 casein:60 whey protein: $\diamond), 9.3 \%$ MKP (80 casein:20 whey protein; $\Delta$ ), and $9.3 \%$ MKP (40 casein:60 whey protein; $\square$ ). AL meal $=$ ad libitum meal. ${ }^{\mathrm{a}-\mathrm{d}}$ Different letters at each measured time are different between treatment according to adjusted Tukey-Kramer $(P<$ $0.05)$.

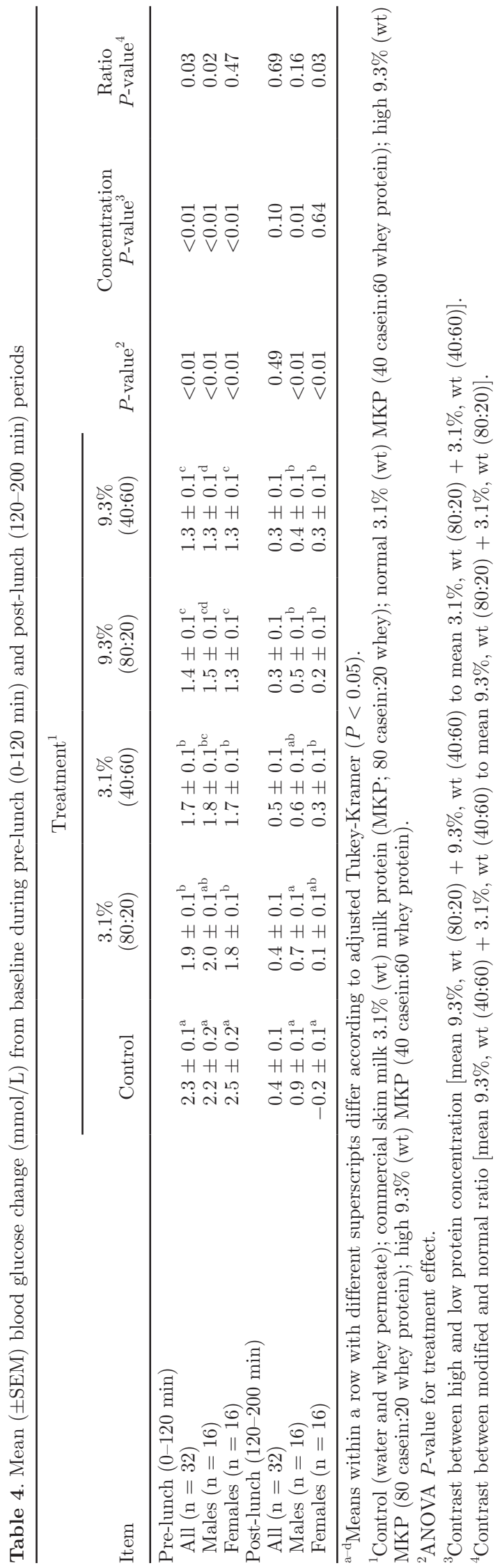


Pre-lunch appetite change from baseline showed a significant effect of time $(P<0.01)$, but not of treatment $(P=0.15)$ or sex $(P=0.06)$, and we noted no treatment $\times$ time $(P=1.00)$ or treatment $\times \operatorname{sex}(P=$ 0.38 ) interactions; thus, data for the sexes were pooled (Figure 3). Normal (80:20) ratio resulted in lower appetite when contrasted with the modified (40:60) protein ratio $(-5.97 \pm 2.38 \mathrm{~mm}, P=0.01)$, and we found no difference between high $(9.3 \%$, wt) and low $(3.1 \%$, wt) protein concentrations $(P=0.97$; Table 6$)$. These contrasting results observed in pooled participants may have been driven by males, specifically as normal (80:20) versus modified (40:60) ratio showed lower appetite $(-8.9 \pm 3.2 \mathrm{~mm}, P<0.01)$; although we observed no difference between high $(9.3 \%$, wt) and low $(3.1 \%$, wt) protein concentrations $(P=0.49)$. Higher appetite with modified protein ratio treatments was not found at specific time points in male and pooled participants. Within female participants, we observed no treatment effect when treatments were compared with each other or in contrast groups $(P>0.05)$.

In terms of post-lunch appetite, main effects of time $(P<0.01)$, treatment $(P<0.01)$, and sex $(P=0.01)$ and a treatment $\times$ sex interaction $(P=0.04)$, but no treatment $\times$ time interactions $(P=1.0)$, were observed (Figure 3). Post-lunch appetite change from baseline was attenuated with the $9.3 \%$ (wt; 80:20) treatment $(-37.6 \pm 1.7 \mathrm{~mm})$ relative to the whey permeate water control $(-32.7 \pm 1.6 \mathrm{~mm} ; P<0.05$; Table 6$)$. Female post-lunch appetite change from baseline showed effects of treatment $(P=0.02)$ and time $(P<0.01)$, but no treatment $\times$ time interaction $(P=1.0)$. Similarly, male participants post-lunch appetite change from baseline showed effects of treatment $(P=0.02)$ and time $(P<$ $0.01)$, but no treatment $\times$ time interaction $(P=1.0)$. When expressed as a mean change from baseline over the post-lunch period for the 5 breakfasts, including the control, males had a lower subjective appetite score $(-40.9 \pm 17.8 \mathrm{~mm})$ than females $(-27.8 \pm 1.0 \mathrm{~mm})$. However, in both sexes and comparing all 5 breakfast meals, the $9.3 \%$ (wt) normal (80:20) treatment led to the greatest suppression of appetite from baseline. This was true in males $(-44.4 \pm 2.2 \mathrm{~mm})$ relative to nondairy protein water control $(-36.6 \pm 2.5 \mathrm{~mm} ; P$ $<0.01)$, but not commercial milk (3.1\%, wt, 80:20; $P=0.35)$, and in females $(-31.2 \pm 2.5 \mathrm{~mm})$, relative to the commercial milk formula $(-25.4 \pm 2.5 \mathrm{~mm} ; P$ $<0.05)$, but not to the control $(-28.9 \pm 2.0 \mathrm{~mm} ; P$ $=0.87$ ). In pooled participants, significant differences were found when high $(9.3 \%$, wt) protein concentration was contrasted to low $(3.1 \%$, wt) protein concentration $(-7.18 \pm 2.26 \mathrm{~mm} ; P<0.01)$, but we found no dif- 


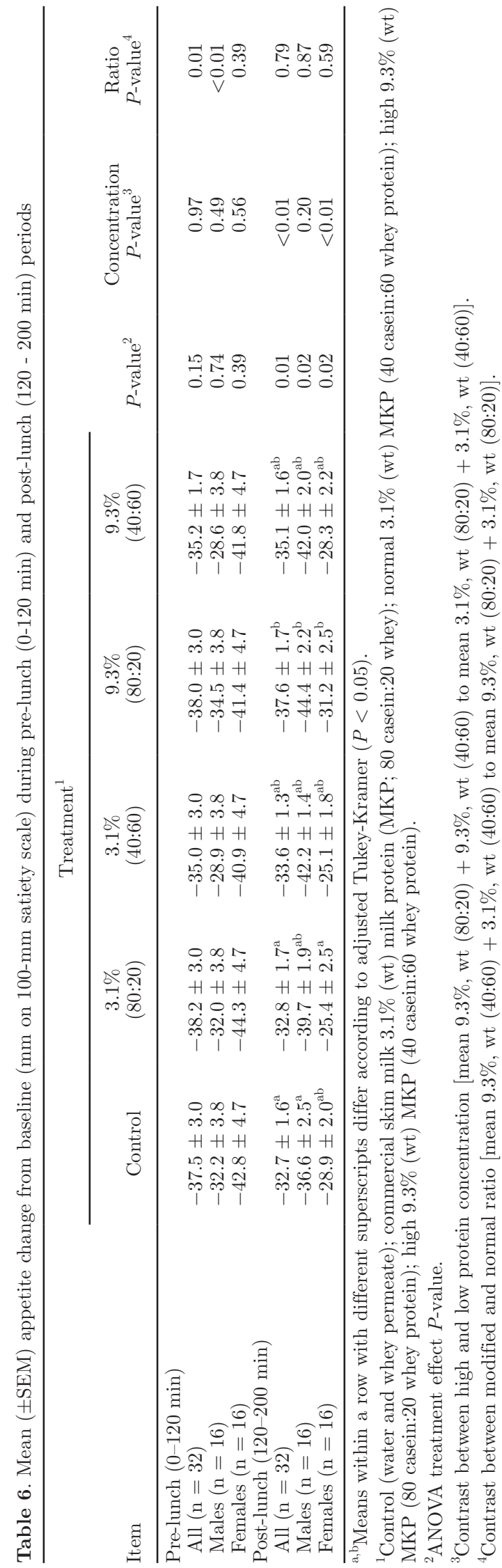

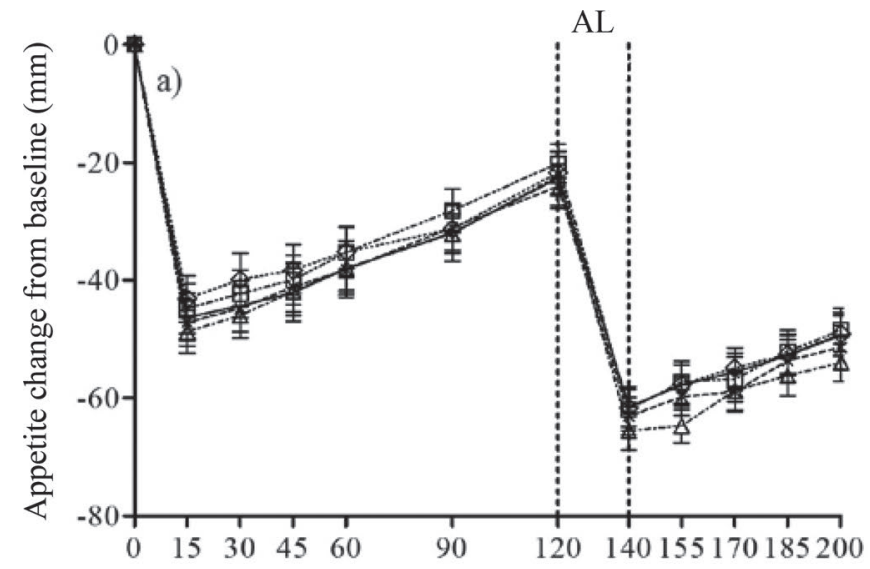
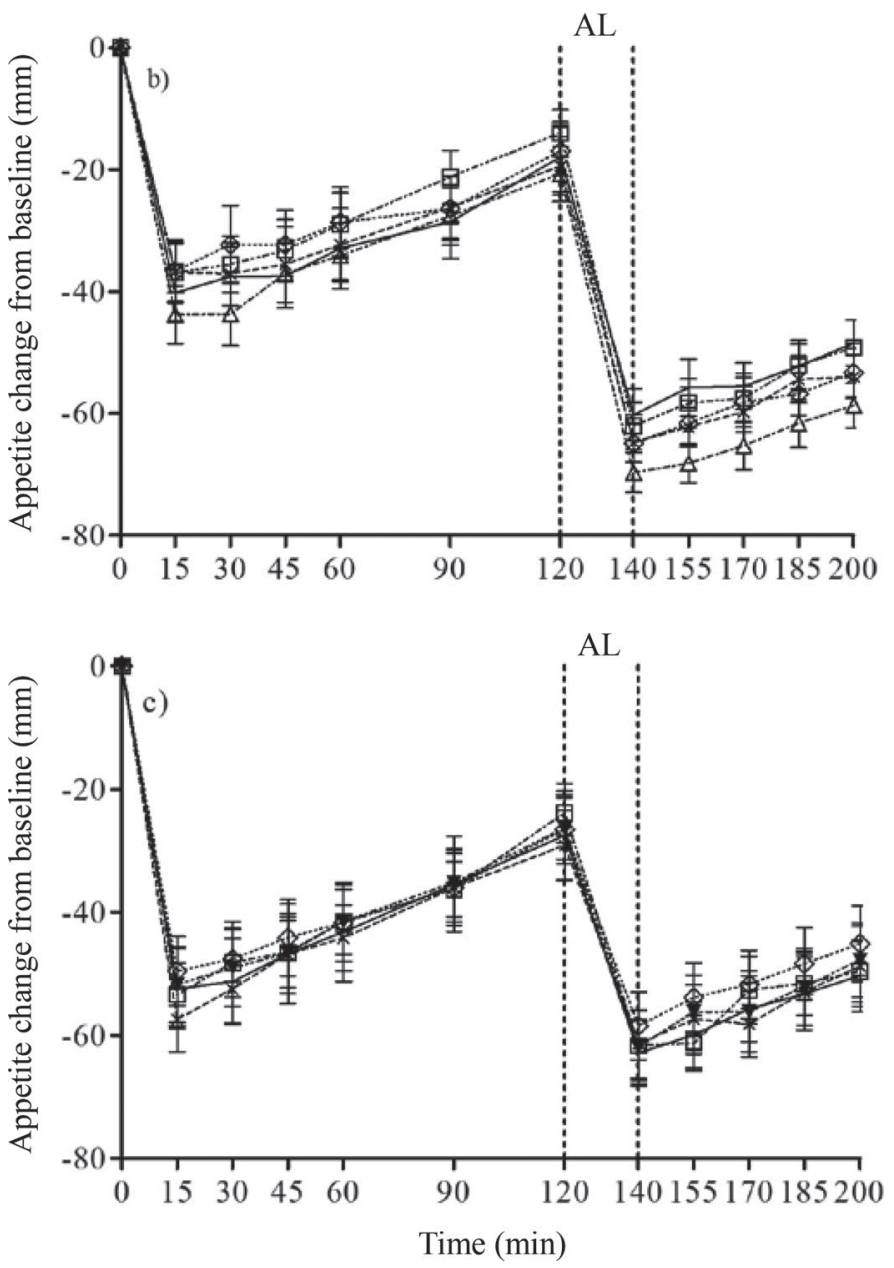

Figure 3. Mean $( \pm \mathrm{SEM})$ ratings of appetite change from baseline for (a) all participants $(\mathrm{n}=32)$, (b) male participants $(\mathrm{n}=16)$, and (c) female participants $(\mathrm{n}=16)$ for control $(+), 3.1 \%$ milk protein (MKP; 80 casein:20 whey protein; $\times$ ), $3.1 \%$ MKP (40 casein:60 whey protein; $\diamond$ ), $9.3 \%$ MKP (80 casein:20 whey protein; $\Delta$ ), and $9.3 \%$ MKP (40 casein:60 whey protein; $\square$ ) for pre-lunch (0-120 min) and post-lunch (120-200 min). Statistical significance at $P<0.05$. AL $=$ ad libitum meal. 
ference between modified (40:60) and normal (80:20) protein ratio $(P=0.79)$. Similar findings were mirrored by high $(9.3 \%$, wt) protein concentration treatments lowered appetite compared with low $(3.1 \%$, wt) protein concentration $(-10.19 \pm 3.13 \mathrm{~mm}, P<0.01)$, but we noted no difference between ratios $(P=0.59)$ in female participants, which may have driven the results in the pooled contrast. We found no difference when high $(9.3 \%, \mathrm{wt})$ was contrasted to low $(3.1 \%, \mathrm{wt})$ protein $(P=0.20)$ and between modified (40:60) and normal $(80: 20)$ ratio $(P=0.87)$ in male post-lunch change from baseline.

Pre-lunch appetite tAUC was not affected by treatment $(P=0.96)$, but was affected by sex $(P=0.01)$, and we observed no treatment $\times$ sex interaction $(P$ $=0.64)$. Likewise, we found no difference when high protein $(9.3 \%$, wt) was contrasted to low $(3.1 \%$, wt) protein concentration $(P=0.48)$ nor when modified (40:60) and normal (80:20) protein ratio $(P=0.77)$ was contrasted. Sex differences may explain this, as males had higher appetite tAUC values than females $(5,596.4$ \pm 170.7 and $4,038.8 \pm 238.8 \mathrm{~mm} \cdot \mathrm{min}$, respectively). Post-lunch appetite tAUC values were not associated with treatment $(P=0.22)$ or sex $(P=0.37)$ and we found no treatment $\times$ sex interaction $(P=0.70)$. However, contrasts between high $(9.3 \%$, wt) protein concentration treatments indicated lower appetite tAUC compared with low $(3.1 \%$, wt) protein concentration
$(-466.24 \pm 199.02 \mathrm{~mm} \cdot \mathrm{min}, P=0.02)$, mirroring the above change from baseline contrast trend in pooled participants, and no difference between normal (80:20) and modified (40:60) ratio $(P=0.69)$.

\section{Food Intake}

At the lunch meal, male participants consumed an average $879.1 \pm 29.12 \mathrm{kcal}$ of the cheese pizza whereas female participants consumed $503.7 \pm 20.7 \mathrm{kcal}$. Two female participants' energy intake results were omitted due to low average calorie consumption at the lunch meal ( $<150 \mathrm{kcal})$, which is not representative of lunch caloric consumption $2 \mathrm{~h}$ after breakfast (Akhavan et al., 2010). We found no significant effect of treatment observed within pooled participants $(P=0.16)$ and no overall treatment $\times$ sex interaction $(P=0.46)$, although we did note an effect of $\operatorname{sex}(P<0.01$; Figure 4$)$. There were no differences when high $(9.3 \%$, wt) protein concentration was contrasted to low $(3.1 \%$, wt) protein concentration $(P=0.53)$ or when modified $(40: 60)$ was contrasted to normal $(80: 20)$ protein ratio $(P=0.12)$ in pooled participants. We observed no treatment effect within males $(P=0.40)$; however, female participants showed a treatment effect on food intake $(P<0.01)$. The modified protein ratio 40:60 treatments resulted in fewer calories consumed contrasted to the 80:20 ratio treatments $(-157.52 \pm 29.37 \mathrm{kcal}, P=0.01)$, but we

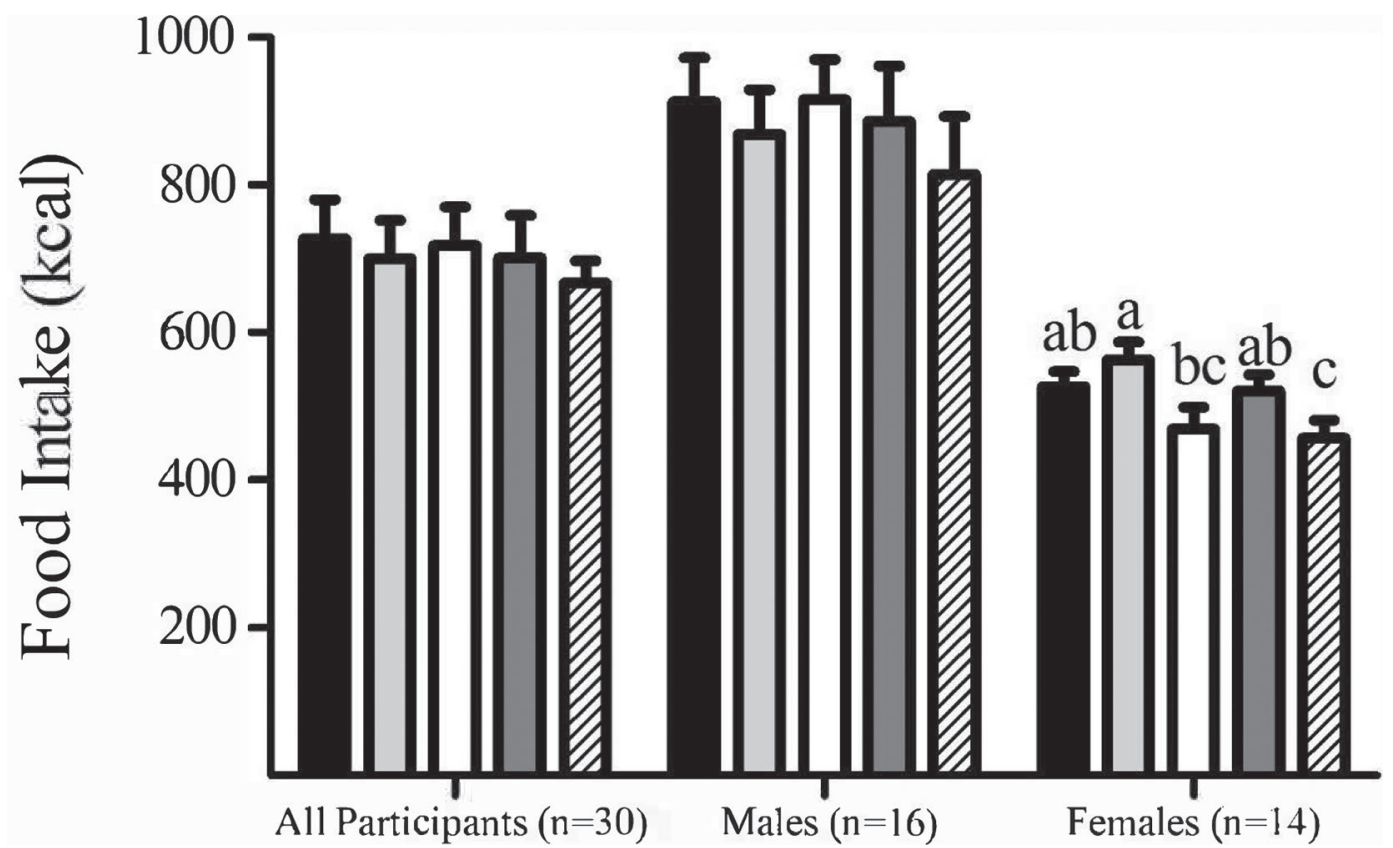

Figure 4. Mean ( \pm SEM) pizza lunch energy intake (kcal) for all participants $(\mathrm{n}=30, P=0.16)$, male participants $(\mathrm{n}=16, P=0.40)$, and female participants $(\mathrm{n}=12, P=0.01$ ) for control (black), 3.1\% milk protein (MKP; 80 casein:20 whey protein; light gray), $3.1 \%$ MKP (40 casein:60 whey protein; white), 9.3\% MKP (80 casein:20 whey protein; dark gray), and 9.3\% MKP (40 casein:60 whey protein; striped) at 120 min. Statistical significance at $P<0.05$. 
found no difference between high $(9.3 \%$, wt) and low $(3.1 \%$, wt $)$ protein concentration $(P=0.08)$.

\section{Appetite and Food Intake Correlation}

Pre-lunch appetite change from baseline $(\mathrm{mm})$ and food intake (kcal) were correlated for all 4 treatments and control beverage and in all participants $(P<0.05$, $\left.\mathrm{R}^{2}=0.04\right)$, but not in either male $\left(P=0.64, \mathrm{R}^{2}=\right.$ $0.0)$ or female $\left(P=0.75, \mathrm{R}^{2}=0.0\right)$ groups (Figure 5$)$. Post-lunch food intake (kcal) and appetite $(\mathrm{mm})$ were inversely correlated for all $\left(P<0.01, \mathrm{R}^{2}=0.24\right)$, male $\left(P<0.01, \mathrm{R}^{2}=0.14\right)$, and female participants $(P<$ $0.01, \mathrm{R}^{2}=0.23$; Figure 5$)$. Two female participants with low lunch meal consumption $(<150 \mathrm{kcal})$ were not included in the correlation.

\section{Palatability and Gastrointestinal Questionnaire}

Overall, palatability of the breakfast significantly differed $(P<0.05)$ between the control and milk treatments, with the $9.3 \%$ (wt, 80:20) treatment being most preferred $(60.3 \pm 3.9 \mathrm{~mm})$ and the whey permeate control being rated the least palatable $(37.3 \pm 4.1$ $\mathrm{mm}$ ). The inclusion of $1.5 \mathrm{~g}$ of crushed acetaminophen (Tylenol, McNeil Consumer Healthcare) to each 250$\mathrm{mL}$ serving of treatment, for the purposes of measuring gastric emptying (data not shown), may have affected palatability. Palatability of the pizza did not differ between study visits (mean score $73.5 \pm 1.22 \mathrm{~mm} ; P=$ $0.87)$.

Gastrointestinal function was recorded by participants $24 \mathrm{~h}$ following each study visit on a $100-\mathrm{mm}$ scale. These were analyzed for differences between treatments and control and also compared with the gastrointestinal function data collected from participants at the time of prescreening (referred to as baseline). We found no differences in overall gastrointestinal function $(P=0.74)$ between all 4 treatments and the control. However, some slight differences were seen when comparing gastrointestinal function $24 \mathrm{~h}$ after the study visit to that at the time of prescreening. Problems with abdominal
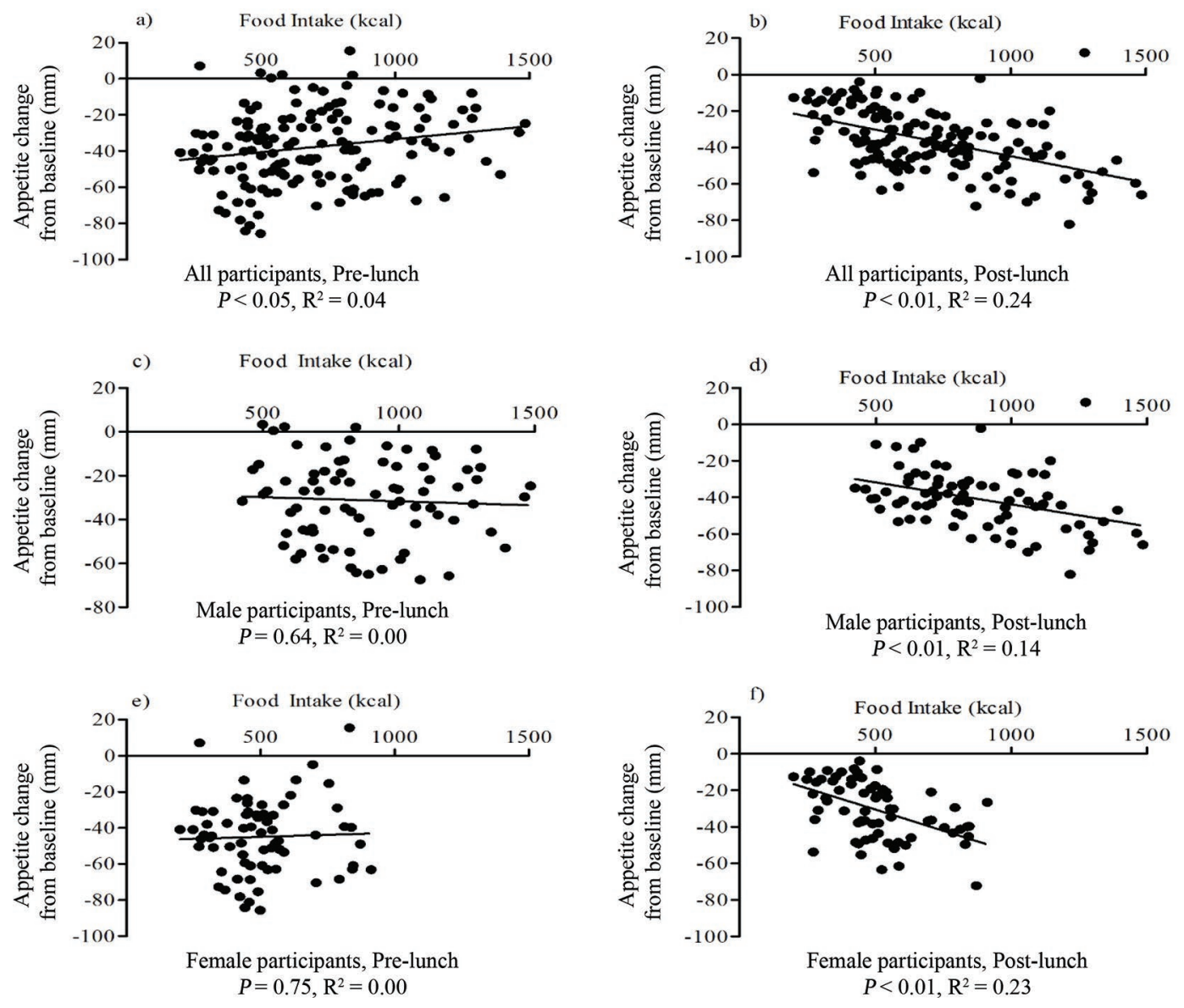

Figure 5. Correlations between food intake (kcal) and appetite change from baseline $(\mathrm{mm} \times \mathrm{min})$ for 4 treatments and the control for prelunch (0-120 min) and post-lunch (120-200 min) periods for $(\mathrm{a}, \mathrm{b})$ all participants $(\mathrm{n}=30),(\mathrm{c}, \mathrm{d})$ males $(\mathrm{n}=16)$, and $(\mathrm{e}, \mathrm{f})$ females $(\mathrm{n}=14)$. 
discomfort (scored from none to worst possible, 0-100 $\mathrm{mm}$ ) increased after consumption of treatment meals and control compared with baseline $(P=0.04)$, particularly the $3.1 \%$ [wt, 80:20; median 0 (interquartile range 0-19); $P<0.01$ ] and 3.1\% [wt, 40:60; $0(0-29) ; P<$ $0.01]$ treatments. Cramping (scored from none to worst possible, $0-100 \mathrm{~mm}$ ) increased after the consumption of 3 treatments and control [0 (0-9); $P<0.05]$, except for the $9.3 \%$ (wt, 40:60) treatment [0 $(0-0) ; P=0.20]$, compared with baseline value of $0(0-0)$. Flatulence (scored from none to worst possible, $0-100 \mathrm{~mm}$ ) increased after consumption of the all treatments and control $[9$ (0-30)] compared with baseline value of $0(0-12.5 ; P$ $=0.04$ ). Problems with defecation (scored from none to worst possible, 0-100 $\mathrm{mm}$ ) increased after consumption of all treatments and control [7.5 (2-23)] compared with baseline value of $1(0-3 ; P<0.01)$. Bowel urgency (scored from not urgent to worst possible, 0-100 mm) increased with all treatments and control [25 (13-48)] compared with baseline value of $5.5(1-26.5 ; P=0.02)$. Last, overall gastric function (scored from perfect to worst possible, $0-100 \mathrm{~mm}$ ) increased in all treatments and control $[22(13-40)]$ compared with baseline value of $10(4-17 ; P<0.01)$.

\section{DISCUSSION}

Consumption of milk products with enhanced protein concentration $(9.3 \%$, wt), when compared with commercial milk $(3.1 \%$, wt) concentration, reduced postprandial BG and lowered post-lunch satiety, but had no effect on pre-lunch feelings of satiety, food intake at the pizza lunch meal, or post-lunch meal BG concentrations. Modifying the casein-to-whey ratio from 80:20 to 40:60 had a modest effect on lowering pre-lunch BG, regardless of protein concentration, whereas the normal casein-to-whey (80:20) ratio had lower pre-lunch Appetite than the treatments with proportionally more whey.

The pre-lunch (0-120 min) results support our hypothesis that the high protein $(9.3 \%)$ modified ratio (40:60) milk treatment with breakfast cereal would result in the lowest postprandial BG concentrations and iAUC values relative to the protein-free control. The greater reduction in BG with high-protein beverages is consistent with previous studies (Anderson et al., 2011; Panahi et al., 2013). The high-protein milks with 27.9 $\mathrm{g}$ of protein resulted in the lowest mean postprandial BG concentration compared with the low-protein milks containing $12.4 \mathrm{~g}$. This result is comparable to Akhavan et al. (2010), who showed dose-dependent BG attenuation following consumption of 20,30 , and $40 \mathrm{~g}$ of whey protein, compared with $10 \mathrm{~g}$, until $140 \mathrm{~min}$. The lack of differences between the normal (80:20) and modified
(40:60) protein ratio on BG iAUC was consistent with another study that compared a control casein-to-whey protein $(2.8: 1 ; 4.51 \mathrm{~g}$ of total protein) ratio against modified casein-to-whey protein (1.5:1) ratio in yogurt (4.49 g of total protein) in healthy men (Doyon et al., 2015). The increased whey protein concentration and modified ratio treatment combined with cereal meant that the treatment with the most whey protein $(14.1 \mathrm{~g}$ of whey protein) had the lowest iAUC BG. This inverse relationship may relate to the fact that whey protein is insulinemic, resulting in a stronger influence on BG compared with casein (Luhovyy et al., 2007; Nilsson et al., 2004). However, the reduction of BG in the current study by complete milk proteins is consistent with other evidence of insulin-independent actions, including delayed gastric emptying and stimulation of the release of glucoregulatory hormones (Panahi et al., 2013; Akhavan et al., 2014).

We anticipated that the higher-protein milks would promote feelings of satiety and decrease subsequent food intake. However, pre-lunch appetite changes from baseline and food intake were not different from control and across the milk treatments. The lack of effect of the differences in protein content of the beverages on appetite and food intake was surprising, but may be explained by several factors, including the high energy content of the treatments when combined with 2 servings of cereal, the time between the treatments and the meal, the differences in palatability of the treatments, the low food intakes of the female participants compared with male participants, and the high lactose content of the beverages. In our study, the breakfast meal of 2 servings of Honey Nut Cheerios ( $58 \mathrm{~g}$ total) and $250 \mathrm{~mL}$ of beverage provided an energy content varying from 400 to $500 \mathrm{kcal}$. The high energy content was clearly a factor, as the reduction in appetite was similar after the treatment meal compared with the control and remained below baseline to $120 \mathrm{~min}$. This reduction in appetite to $120 \mathrm{~min}$ is consistent with a previous study that found chocolate milk or infant formula with energy contents of 340 and $370 \mathrm{kcal}$, respectively, but not milk with $200 \mathrm{kcal}$, suppressed appetite for $90 \mathrm{~min}$ but not up to $120 \mathrm{~min}$. Food intake at a meal consumed at $30 \mathrm{~min}$, but not 120 min later, reflected differences in appetite suppression (Panahi et al., 2013). Thus, in the present study, the time to the subsequent meal may not have been sufficient for differences in the composition of the treatments to be reflected beyond the effects of their energy content. The palatability of the beverages or the pizza meal did not appear to be a factor, as it was not correlated with either appetite ratings or food intake. Overall, gastrointestinal symptoms measured up to 24 $\mathrm{h}$ post-treatment were not different among treatments and control, but were higher compared with baseline 
ratings collected at screening. The lactose content of the treatments perhaps offers an explanation for this, even though the participants all habitually consumed dairy products. The total lactose content of the beverages was $34.7 \mathrm{~g}$, which is 3 -fold the amount in a typical 250-mL serving of milk. High protein with normal lactose levels could have been achieved with the use of high-protein milk or whey protein concentrates rather than skim powder and whey protein concentrate-35, as was used in the current study. Also, on each study day participants received 12 finger pricks over the course of $3 \mathrm{~h}$. Physical discomfort and stress from finger prick blood sampling can have an influence on glycemic response and antagonize insulin (Brouns et al., 2005), although it is standard for this type of protocol. Steps were taken to seat participants in a comfortable environment and the inclusion of acetaminophen in the study protocol may have partially mitigated pain as a contributing factor to stress.

Sex affected food intake $(P<0.05)$, as females weighed less than males but consumed the same treatment meals. Females appeared fuller after consuming all the treatment meals and maintained a suppressed appetite over time compared with males. This may have led to the opposite effects observed in post-lunch BG, as we observed no treatment effect but suppression of appetite was found. The difference in the contrasts of post-lunch BG change from baseline between sexes may be due to varying food intake, as female participants consumed less than male participants. Appetite suppression during the post-lunch period (120-200 min) by the $9.3 \%$ (wt, 80:20) treatment was observed in pooled and female, but not male, participants. It was previously suggested that $9 \mathrm{~g}$ of combined milk protein should provide observable significance for whey to show an early satisfying effect and casein at a later duration (Anderson et al., 2011). In the current study, we were able to validate the satiating effect of casein in the post-lunch duration, but not the satiating effect of whey during the pre-lunch period. The suppression of appetite with $9.3 \%$ (wt) protein (80:20) suggests that the aggregation and slow-digesting nature of casein may have prolonged the feeling of fullness from the pizza meal. Thus, post-lunch correlation between food intake (kcal) and pre-lunch appetite change from baseline $(\mathrm{mm})$ for all 4 treatments and the control showed an inverse relationship for all $\left(P<0.05, \mathrm{R}^{2}=0.24\right)$, for male $\left(P<0.05, \mathrm{R}^{2}=0.14\right)$, and for female participants $\left(P<0.05, \mathrm{R}^{2}=0.23\right)$. However, an inverse correlation was only found in the pre-lunch period for pooled participants $\left(P<0.05, \mathrm{R}^{2}=0.04\right)$, and not within only male $\left(P=0.64, \mathrm{R}^{2}=0.04\right)$ or within only female $(P=$ $\left.0.75, \mathrm{R}^{2}=0.0\right)$ participants (Figure 5).

\section{CONCLUSIONS}

Milk consumed with breakfast cereal reduced postprandial blood glucose concentration compared with a water control, and high dairy protein concentration $(9.3 \%, \mathrm{wt})$ reduced postprandial blood glucose concentration compared with normal dairy protein concentration $(3.1 \%$, wt). The high $(9.3 \%$, wt) protein concentration treatments also reduced appetite after the second meal compared with the low $(3.1 \%$, wt) protein equivalent. A modest effect of modified (40:60) protein ratio was observed in terms of lower pre-lunch blood glucose change from baseline and normal (80:20) protein ratio lowering pre-lunch appetite change from baseline. However, protein concentration and casein-to-whey ratio did not show effects on food intake at a subsequent meal in pooled participants. Thus, the results can be used to inform future development of milk-based beverages to focus on increase protein concentration to attenuate postprandial glucose and appetite suppression.

\section{ACKNOWLEDGMENTS}

We thank all the study participants and graduate and undergraduate students who assisted with this research. This research is supported mainly by Agriculture and Agri-Food Canada (Ottawa, ON), and by additional contributions from Dairy Farmers of Canada (Ottawa, ON), the Canadian Dairy Network (Guelph, ON), and the Canadian Dairy Commission under the Agri-Science Clusters Initiative (Ottawa, ON) under the Agri-Science Clusters Initiative. As per the research agreement, aside from providing financial support, the funders have no role in the design and conduct of the studies, data collection and analysis, or interpretation of the data. Researchers maintain independence in conducting their studies, own their data, and report the outcomes, regardless of the results. The decision to publish the findings rests solely with the researchers.

\section{REFERENCES}

Akhavan, T., B. L. Luhovyy, P. H. Brown, C. E. Cho, and G. H. Anderson. 2010. Effect of premeal consumption of whey protein and its hydrolysate on food intake and postmeal glycemia and insulin responses in young adults. Am. J. Clin. Nutr. 91:966-975.

Akhavan, T., B. L. Luhovyy, S. Panahi, R. Kubant, P. H. Brown, and G. H. Anderson. 2014. Mechanism of action of pre-meal consumption of whey protein on glycemic control in young adults. J. Nutr. Biochem. 25:36-43.

Anderson, G. H., B. L. Luhovyy, T. Akhavan, and S. Panahi. 2011. Milk proteins in the regulation of body weight, satiety, food intake and glycemia. Nestle Nutr. Workshop Ser. Pediatr. Program 67:147-159. 10.1159/000325581.

Anderson, G. H., and S. E. Moore. 2004. Dietary protein in the regulation of food intake and body weight in humans. J. Nutr. 134:974S979S. 
Anderson, G. H., S. N. Tecimer, D. Shah, and T. A. Zafar. 2004. Protein source, quantity, and time of consumption determine the effect of proteins on short-term food intake in young men. J. Nutr. 134:3011-3015.

Benelam, B. 2009. Satiation, satiety and their effects on eating behavior. Nutr. Bull. 34:126-173.

Blundell, J., C. De Graaf, T. Hulshof, S. Jebb, B. Livingstone, A. Lluch, D. Mela, S. Salah, E. Schuring, K. van der Knaap, and M. Westerterp. 2010. Appetite control: Methodological aspects of the evaluation of foods. Obes. Rev. 11:251-270.

Boirie, Y., M. Dangin, P. Gachon, M. P. Vasson, J. L. Maubois, and B. Beaufrère. 1997. Slow and fast dietary proteins differently modulate postprandial protein accretion. Proc. Natl. Acad. Sci. U.S.A. 94:14930-14935

Brouns, F., I. Bjorck, K. N. Frayn, A. L. Gibbs, V. Lang, G. Slama, and T. M. Wolever. 2005. Glycaemic index methodology. Nutr. Res. Rev. 18:145-171.

Dangin, M., Y. Boirie, C. Guillet, and B. Beaufrère. 2002. Influence of the protein digestion rate on protein turnover in young and elderly subjects. J. Nutr. 132:3228S-3233S.

Doyon, C. Y., A. Tremblay, L. E. Rioux, C. Rhéaume, K. Cianflone, P. Poursharifi, and S. L. Turgeon. 2015. Acute effects of protein composition and fibre enrichment of yogurt consumed as snacks on appetite sensations and subsequent ad libitum energy intake in healthy men. Appl. Physiol. Nutr. Metab. 40:980-989.

Eckel, R. H., S. M. Grundy, and P. Z. Zimmet. 2005. The metabolic syndrome. Lancet 365:1415-1428.

Fox, P. F., and P. L. H. McSweeney. 1998. Dairy Chemistry and Biochemistry. Blackie Academic \& Professional, UK.

Hall, W. L., D. J. Millward, S. J. Long, and L. M. Morgan. 2003 Casein and whey exert different effects on plasma amino acid profiles, gastrointestinal hormone secretion and appetite. Br. J. Nutr. 89:239-248.

Health Canada. 2013. Draft Guidance Document on Food Health Claims Related to the Reduction in Post-Prandial Glycaemic Response. Health Products and Food Branch. Ottawa, ON.

Klein, C. J. 2002. Nutrient requirements for preterm infant formulas. J. Nutr. 132:1395S-1577S.
Law, M., P. S. P. Huot, Y. T. Lee, S. Vien, B. L. Luhovyy, and G. H. Anderson. 2017a. The effect of dairy and non-dairy beverages consumed with high glycemic cereal on subjective appetite, food intake and postprandial glycemia in young adults. Appl. Physiol. Nutr. Metab. 42:1201-1209.

Law, M., Y. T. Lee, B. L. T. Luhovyy, and G. H. Anderson. 2017b. The effect of dairy products consumed with high glycemic carbohydrate on subjective appetite, food intake and post-prandial glycemia in older adults. Appl. Physiol. Nutr. Metab. 42:1210-1216.

Luhovyy, B. L., T. Akhavan, and G. H. Anderson. 2007. Whey proteins in the regulation of food intake and satiety. J. Am. Coll. Nutr. 26:704S-712S.

Mamerow, M. M., J. A. Mettler, K. L. English, S. L. Casperson, E. Arentson-Lantz, M. Sheffield-Moore, D. K. Layman, and D. PaddonJones. 2014. Dietary protein distribution positively influences $24-\mathrm{h}$ muscle protein synthesis in healthy adults. J. Nutr. 144:876-880.

Martin, C. R., P. R. Ling, and G. L. Blackburn. 2016. Review of infant feeding: Key features of breast milk and infant formula. Nutrients $8: 279$.

Nilsson, M., M. Stenberg, A. H. Frid, J. J. Holst, and I. M. Björck. 2004. Glycemia and insulinemia in healthy subjects after lactoseequivalent meals of milk and other food proteins: The role of plasma amino acids and incretins. Am. J. Clin. Nutr. 80:1246-1253.

Panahi, S., B. L. Luhovyy, T. Liu, T. Akhavan, D. El Khoury, H. D Goff, and G. H. Anderson. 2013. Energy and macronutrient content of familiar beverages interact with pre-meal intervals to determine later food intake, appetite and glycemic response in young adults. Appetite 60:154-161.

Stunkard, A. J., and S. Messick. 1985. The three-factor eating questionnaire to measure dietary restraint, disinhibition and hunger. J. Psychosom. Res. 29:71-83.

Veenstra, J. M., A. M. Duncan, C. N. Cryne, B. R. Deschambault, J. I. Boye, M. Benali, M. Marcotte, S. M. Tosh, E. R. Farnworth, and A. J. Wright. 2010. Effect of pulse consumption on perceived flatulence and gastrointestinal function in healthy males. Food Res. Int. $43: 553-559$ 